\title{
Methods for Measuring the Time of Transfer from Pediatric to Adult Care for Chronic Conditions Using Administrative Data: A Scoping Review
}

This article was published in the following Dove Press journal: Clinical Epidemiology

\author{
Rayzel Shulman ${ }^{1,2}$ \\ Eyal Cohen ${ }^{3}$ \\ Eric I Benchimol (iD) ${ }^{4}$ \\ Meranda Nakhla $\mathbb{D}^{5,6}$ \\ 'Department of Pediatrics, Division of \\ Endocrinology, The Hospital for Sick \\ Children, Toronto, ON, Canada; \\ ${ }^{2}$ Sickkids Research Institute, Child Health \\ Evaluative Sciences, Toronto, ON, \\ Canada; ${ }^{3}$ Department of Pediatrics, The \\ Hospital for Sick Children, Toronto, ON, \\ Canada; ${ }^{4}$ Department of Pediatrics, \\ Division of Gastroenterology, Children's \\ Hospital of Eastern Ontario, Ottawa, \\ ON, Canada; ${ }^{5}$ Department of Pediatrics, \\ Division of Endocrinology, Montreal \\ Children's Hospital, Montreal, QC, \\ Canada; ${ }^{6}$ Center of Outcomes Research \\ and Evaluation, Research Institute of the \\ McGill University Health Centre, \\ Montreal, QC, Canada
}

\begin{abstract}
Purpose: To describe methods used to identify the timing of transfer from pediatric to adult care within health administrative data and to identify the advantages and limitations of each method to guide future research.
\end{abstract}

Study Design and Settings: We conducted a scoping review to identify studies, summarized challenges of identifying the timing of transfer, and proposed methodological approaches for each.

Results: Studies use the following approaches to capture individuals who transfer from pediatric to adult care by 1) defining the timing of transfer by the last pediatric and first adult care visit last and 2) defining transfer to adult care based on a specific age.

Conclusion: There are important limitations of administrative data that must be recognized in designing studies examining the transfer to adult care.

Keywords: transfer to adult care, administrative data, chronic disease

\section{Introduction}

Approximately $15 \%$ of youth have a chronic health condition that will ultimately require the transfer from pediatric to adult care. ${ }^{1}$ The ultimate goal of transition care is to provide healthcare that is coordinated, uninterrupted, and developmentallyappropriate and to promote skills in decision-making and self-care. ${ }^{2-5}$ However, patients with chronic health conditions and providers report inadequate support and services during the transition to adult care. ${ }^{6-9}$ Emerging adulthood (18-30 years) is a particularly challenging period for people living with a chronic health condition because of the change in type and characteristics of healthcare provision, decreased parental involvement, and the developmental changes emerging adults are undergoing including; emotional, physical, financial, occupational, and social changes within a short period of time. ${ }^{10,11}$ These combined challenges result in an increased risk of inadequate medical follow-up, poor self-management, emergency department visits and hospitalizations. ${ }^{12-15}$

Although the importance of transition care is well recognized, empiric data about transition outcomes remain limited. There continues to be a paucity of research on the magnitude of the problem, on factors that may mitigate the risk of complications around the transition period as well as a lack of intervention trials. ${ }^{16-19}$ It is important to establish rigorous methods to identify the time of transfer to adult care in order to: 1) understand patterns of healthcare visits to pediatric and adult care providers for
Correspondence: Meranda Nakhla Center of Outcomes Research and Evaluation, Research Institute of the McGill University Health Centre, 5252 de Maisonneuve Blvd, W, 3rd Floor,

Montreal, OC H4A 3S5, Canada

Tel + I-5 |4-4I2-4400 Ext 23698

Email meranda.nakhla@mcgill.ca 
transition-age youth (eg, delays in leaving pediatric care, time gaps between final pediatric and first adult visits, and continuity of care after transfer to adult care), and 2) examine the associations of patterns of care during transition-age and important health outcomes.

Health administrative data are powerful tools in health services research to efficiently assess disease burden, healthcare utilization and outcomes in adolescents with chronic illnesses, particularly around the high-risk transition period. Specifically, using administrative data for identifying the time of transfer and for assessing outcome measures such as emergency department visits and hospitalizations may be preferable to alternatives such as selfreports, which are burdensome, may not be feasible, and may have recall bias. Further, administrative data may be useful as a supplement to patient-reported experience and outcome measures that are focused on other aspects of transition. Finally, there are benefits to understanding these issues on a population-level.

However, identifying the timing of transfer from pediatric to adult care can be difficult within health administrative data. An accurate definition for identifying this transfer is essential in reducing the risk of misclassification bias. Recognizing that health systems and administrative data sources vary between settings, it is not possible to design a single definition to identify the time of transfer that is applicable to all contexts. However, there are likely a few general approaches that could be used to measure desired variables depending on local context. Developing standardized methods would increase the quality and reproducibility of data as well as the ability to meaningfully compare results across studies. As such, our aims are to 1) describe the methods used to identify the timing of transfer to adult care within administrative health data and 2) identify the challenges with these methods as well as propose methodological approaches to overcome the challenges.

\section{Methods}

We conducted a scoping review to identify studies that used administrative data to identify the time of transfer to adult care for young adults with a chronic health condition. $^{20}$ We searched Embase (OVID) and Medline and Epub Ahead of Print, In-Process \& Other NonIndexed Citations and Daily(OVID) from the inception of the databases to August 22, 2019. The search included two broad concepts: 1) youth transferring to adult care, and 2) health administrative data. Search terms were identified through known articles on this topic, subject experts on the team, and a librarian with expertise in database searching. The search terms included combinations of controlled vocabulary specific to the databases (ie, EmTree or $\mathrm{MeSH}$ ) and keyword terms searched in the title, abstract or author keyword fields. The search was limited only to English language articles. Search strategies are available in Appendix A. We included papers that 1) determined the time of transfer from pediatric to adult care, and 2) used administrative data; routinely collected data about health services use (eg, physician billing data and hospital and emergency department visits). All study designs were eligible and studies of any chronic condition requiring transfer to adult care were included.

Two reviewers (R.S. and M.N.) independently screened the search results, obtained the full-text of potentially eligible studies, and determined their eligibility. Discrepancies were resolved by discussion. We described each study and identified methodological approaches used by each to address specific challenges related to identification of the timing of transfer within administrative data.

\section{Results}

Among the 241 records identified through our database search, 14 studies were included (Figure 1). Table 1 describes the definitions used to identify the transfer to adult care using administrative health data. Five studies use a "transfer period" based on the date of last pediatric care visit and first adult care visit during which transfer to adult care is assumed to have occurred. ${ }^{21-25}$ These visits were defined based on the specialty of the provider. Nine other studies defined the timing of transfer based on a fixed age, assuming that transfer occurred at that

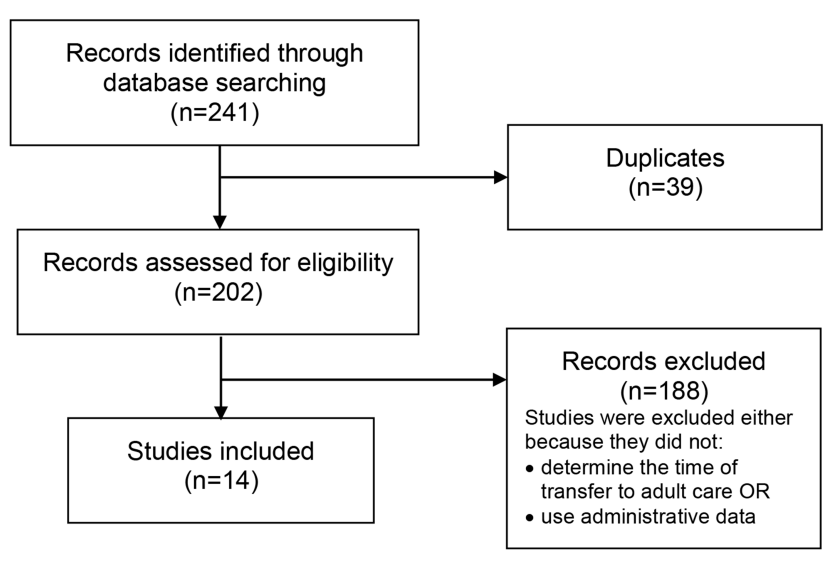

Figure I Flow diagram. 
Table I Study Characteristics and Methods

\begin{tabular}{|c|c|c|c|c|c|}
\hline $\begin{array}{l}\text { First } \\
\text { Author } \\
\text { and Year of } \\
\text { Publication }\end{array}$ & Location & Data Source & Disease Focus & $\begin{array}{l}\text { Study } \\
\text { Design }\end{array}$ & Methodology \\
\hline \multicolumn{6}{|c|}{ Studies that define time of transfer based on last pediatric and first adult visits } \\
\hline $\begin{array}{l}\text { Bollegala } \\
2017^{21}\end{array}$ & $\begin{array}{l}\text { Ontario, } \\
\text { Canada }\end{array}$ & $\begin{array}{l}\text { Population-based health } \\
\text { administrative data }\end{array}$ & $\begin{array}{l}\text { Inflammatory bowel } \\
\text { disease (IBD) }\end{array}$ & $\begin{array}{l}\text { Retrospective } \\
\text { cohort }\end{array}$ & $\begin{array}{l}\text { "pre-transfer": } 2 \text { years before the last } \\
\text { pediatric visit } \\
\text { "transfer of care": time between last } \\
\text { pediatric visit and first adult visit } \\
\text { occurring at age } \geq 18 \\
\text { "post-transfer": time from the first adult } \\
\text { visit onward for } 2 \text { years }\end{array}$ \\
\hline Hale $2017^{22}$ & England & $\begin{array}{l}\text { Routine hospital } \\
\text { administrative data }\end{array}$ & Diabetes & $\begin{array}{l}\text { Retrospective } \\
\text { cohort }\end{array}$ & $\begin{array}{l}\text { "Successful transition" = any adult } \\
\text { service contact within } 6 \text { months of last } \\
\text { paediatric contact. "Successful } \\
\text { retention" = first planned adult contact } \\
\text { within } 6 \text { months of the last planned } \\
\text { paediatric contact, and at least } 2 \text { further } \\
\text { adult contacts within the next } 2 \text { years }\end{array}$ \\
\hline $\begin{array}{l}\text { Mannion } \\
2016^{23}\end{array}$ & $\begin{array}{l}\text { United } \\
\text { States }\end{array}$ & $\begin{array}{l}\text { National commercial } \\
\text { insurance administrative } \\
\text { claims database }\end{array}$ & $\begin{array}{l}\text { Juvenile idiopathic } \\
\text { arthritis (IIA) }\end{array}$ & $\begin{array}{l}\text { Retrospective } \\
\text { cohort }\end{array}$ & $\begin{array}{l}\text { The first adult visit was defined as the } \\
\text { transfer point; this resulted in } 3 \text { distinct } \\
\text { intervals: pediatric, transfer, and adult }\end{array}$ \\
\hline Wisk $2015^{24}$ & $\begin{array}{l}\text { United } \\
\text { States }\end{array}$ & $\begin{array}{l}\text { Harvard Pilgrim Health } \\
\text { Care Claims Data }\end{array}$ & $\begin{array}{l}\text { Children with chronic } \\
\text { conditions and healthy } \\
\text { children }\end{array}$ & $\begin{array}{l}\text { Retrospective } \\
\text { Cohort }\end{array}$ & $\begin{array}{l}\text { Timing of transfer measured from } 16 \\
\text { years to first adult-focused primary care } \\
\text { provider visit } \\
\text { Transfer date: date of first adult-focused } \\
\text { primary care visit }\end{array}$ \\
\hline Zhao $2018^{25}$ & $\begin{array}{l}\text { Ontario, } \\
\text { Canada }\end{array}$ & $\begin{array}{l}\text { Population-based health } \\
\text { administrative data }\end{array}$ & $\begin{array}{l}\text { Inflammatory bowel } \\
\text { disease (IBD) }\end{array}$ & $\begin{array}{l}\text { Retrospective } \\
\text { cohort }\end{array}$ & $\begin{array}{l}\text { Transfer period: time between first } \\
\text { adult gastroenterologist visit and the } \\
\text { last pediatric gastroenterologist visit. }\end{array}$ \\
\hline \multicolumn{6}{|c|}{ Studies that defined time of transfer based on age } \\
\hline $\begin{array}{l}\text { Blinder } \\
2015^{26}\end{array}$ & $\begin{array}{l}\text { United } \\
\text { States }\end{array}$ & $\begin{array}{l}5 \text { US State Medicaid } \\
\text { databases }\end{array}$ & Sickle cell Disease & $\begin{array}{l}\text { Retrospective } \\
\text { cohort }\end{array}$ & $\begin{array}{l}\text { 18th birthday was defined as the age of } \\
\text { transfer }\end{array}$ \\
\hline $\begin{array}{l}\text { Cohen } \\
2016^{27}\end{array}$ & $\begin{array}{l}\text { Ontario, } \\
\text { Canada }\end{array}$ & $\begin{array}{l}\text { Population-based health } \\
\text { administrative data }\end{array}$ & $\begin{array}{l}\text { Chronic health } \\
\text { conditions }\end{array}$ & $\begin{array}{l}\text { Retrospective } \\
\text { cohort }\end{array}$ & $\begin{array}{l}\text { 18th birthday was defined as the age of } \\
\text { transfer }\end{array}$ \\
\hline $\begin{array}{l}\text { Dickerson } \\
2012^{28}\end{array}$ & $\begin{array}{l}\text { United } \\
\text { States }\end{array}$ & $\begin{array}{l}\text { Administrative data from } 25 \\
\text { children's hospitals within } \\
\text { the Pediatric Health } \\
\text { Information System (PHIS), }\end{array}$ & Sickle cell disease & $\begin{array}{l}\text { Retrospective } \\
\text { cohort }\end{array}$ & $\begin{array}{l}\text { 18th birthday was defined as the age of } \\
\text { transfer }\end{array}$ \\
\hline $\begin{array}{l}\text { Nakhla } \\
2009^{13}\end{array}$ & $\begin{array}{l}\text { Ontario, } \\
\text { Canada }\end{array}$ & $\begin{array}{l}\text { Population-based health } \\
\text { administrative data }\end{array}$ & Diabetes & $\begin{array}{l}\text { Retrospective } \\
\text { cohort }\end{array}$ & $\begin{array}{l}\text { 18th birthday was defined as the age of } \\
\text { transfer }\end{array}$ \\
\hline Reilly $2017^{29}$ & Sweden & $\begin{array}{l}\text { Population-based Swedish } \\
\text { Inpatient Register }\end{array}$ & Celiac Disease & $\begin{array}{l}\text { Retrospective } \\
\text { Cohort }\end{array}$ & $\begin{array}{l}\text { Pre-transition age: } 16-17 \text { years } \\
\text { Post-transition age: } 19-20 \text { years }\end{array}$ \\
\hline
\end{tabular}

(Continued) 
Table I (Continued).

\begin{tabular}{|l|l|l|l|l|l|}
\hline $\begin{array}{l}\text { First } \\
\text { and Year of } \\
\text { Publication }\end{array}$ & Location & Data Source & Disease Focus & $\begin{array}{l}\text { Study } \\
\text { Design }\end{array}$ & Methodology \\
\hline $\begin{array}{l}\text { Shulman } \\
2018^{15}\end{array}$ & $\begin{array}{l}\text { Ontario, } \\
\text { Canada }\end{array}$ & $\begin{array}{l}\text { Population-based health } \\
\text { administrative data }\end{array}$ & Diabetes & $\begin{array}{l}\text { Retrospective } \\
\text { cohort }\end{array}$ & $\begin{array}{l}\text { Pre-transition age: 15-17 years } \\
\text { Transition-age: 17-19 years } \\
\text { Early adulthood: 19-26 years (end of } \\
\text { study) }\end{array}$ \\
\hline Singh 201930 & $\begin{array}{l}\text { Wisconsin, } \\
\text { United } \\
\text { States }\end{array}$ & Medicaid Data & Sickle Cell Disease & $\begin{array}{l}\text { Retrospective } \\
\text { Cohort }\end{array}$ & Transition age: 19 years \\
\hline $\begin{array}{l}\text { Toulany } \\
2019^{31}\end{array}$ & $\begin{array}{l}\text { Ontario, } \\
\text { Canada }\end{array}$ & $\begin{array}{l}\text { Population-based health } \\
\text { administrative data }\end{array}$ & Mental illness & $\begin{array}{l}\text { Retrospective } \\
\text { cohort }\end{array}$ & $\begin{array}{l}\text { Pre-transition: 12-16 years } \\
\text { During transition: 17-18 years } \\
\text { After transition: 19-26 years }\end{array}$ \\
\hline $\begin{array}{l}\text { Wijlaars } \\
2018^{32}\end{array}$ & England & $\begin{array}{l}\text { Hospital Episode Statistics } \\
\text { Admitted Patient Care data }\end{array}$ & $\begin{array}{l}\text { Long-term conditions } \\
\text { (LTCs) (defined using } \\
\text { the International } \\
\text { Classification of } \\
\text { Diseases) }\end{array}$ & $\begin{array}{l}\text { Cross- } \\
\text { sectional } \\
\text { study }\end{array}$ & $\begin{array}{l}\text { Pre-transition (ages 10-15 years) and } \\
\text { after transition (19-24 years) }\end{array}$ \\
\hline
\end{tabular}

age. $^{13,15,26-32}$ In Table 2, we summarize the challenges in identifying the timing of transfer as well as the methods that can be used to address each challenge.

\section{Identifying Time of Transfer Based on Pediatric and Adult Visits}

Using the number and timing of pediatric and adult visits is one strategy that has been used to identify the time of transfer. To define the time of transfer studies have specified the number of visits to an adult and a pediatric provider, established a minimum time before and after the first adult visit, set a maximum time in the transfer period, and set a minimum number of visits to an adult provider. ${ }^{22,23,25,33}$ To measure continuity of care after transfer, Hale et al defined successful retention as having the first adult contact within six months of the last paediatric contact and then at least two subsequent adult contacts within the next two years. $^{22}$ To address the challenge of identifying pediatric vs adult visits, Wisk et al used provider specialty codes from claims data to categorize providers as pediatric- or adult-focused primary care providers and then defined the time of transfer as the first adult-focused visit and the transfer gap as the time from last pediatric-focused visit to first adult-focused visit. $^{24}$ To ensure that transfer of care was due to age and not geographic relocation, Mannion et al set a minimum age for inclusion at the time of transfer. ${ }^{23}$

\section{Identifying Time of Transfer in Shared Care Models}

Identifying the timing of transfer based on pediatric and adult care visits and specifically for individuals who have "shared care" defined as a pediatric visit occurring after the first adult visit presents researchers with many methodologic dilemmas on how to accurately identify transfer. Defining a transfer period is one approach used to identify the time of transfer for individuals who have a shared care model. For example, Zhao et al defined a transfer period as the time between the first adult visit and the last pediatric visit. If during this period there was shared care from both a pediatric and adult provider, the transfer period duration was assigned as the number of days from the first adult visit to the final pediatric visit. ${ }^{25}$ To identify individuals who had shared care, Mannion et al required that individuals have a pediatric visit followed by an adult visit and without a subsequent pediatric visit. $^{23}$

\section{Measuring Disease Onset, Exposures, and Outcomes Relative to the Time of Transfer}

To ensure that individuals were diagnosed with a chronic condition requiring transfer to adult care, longitudinal data are needed to capture diagnoses prior to transfer to ensure 
Table 2 Approaches to Identifying the Timing of Transfer to Adult Care Within Health Administrative Data

\begin{tabular}{|c|c|}
\hline Challenges of Identifying the Timing of Transfer to Adult Care & $\begin{array}{l}\text { Methodological Approaches to Address Each Specific } \\
\text { Challenge of Identifying the Time of Transfer }\end{array}$ \\
\hline Identifying timing of transfer based on pediatric and adult visits & $\begin{array}{l}\text { - Define time of transfer based on the number and timing of pediatric } \\
\text { and adult visit. }{ }^{22,23,25} \\
\text { - Measure continuity of care after the initial adult visit. }{ }^{22} \\
\text { - Use provider specialty codes from claims data to categorize providers } \\
\text { - Set a minimum age at time of transfer to ensure that the transfer was } \\
\text { due to age and not geographic relocation. }{ }^{23}\end{array}$ \\
\hline $\begin{array}{l}\text { Identifying the timing of transfer for individuals who have "shared care" } \\
\text { ie a pediatric visit occurring after the first adult visit }\end{array}$ & $\begin{array}{l}\text { - Definition of a transfer period from the first adult visit to the final } \\
\text { pediatric visit. } \\
\text { - Specify that individuals must have a pediatric visit followed by an adult } \\
\text { visit and without a subsequent pediatric visit. }{ }^{23}\end{array}$ \\
\hline $\begin{array}{l}\text { Measuring disease onset, exposures, and outcomes relative to the } \\
\text { timing of transfer }\end{array}$ & $\begin{array}{l}\text { - Use longitudinal data to capture diagnoses prior to transfer to ensure } \\
\text { that the condition existed prior to receipt of adult care. }{ }^{32} \\
\text { - Measure outcomes after a washout period that starts after the first } \\
\text { adult visit. }{ }^{25} \\
\text { - Measure exposures and outcomes immediately before and after } \\
\text { a specific assumed date of transfer (eg, } 18 \text { th birthday) })^{13,26-28} \text { or } \\
\text { a period of time within which transfer is assumed to occur. }{ }^{15,29-31}\end{array}$ \\
\hline Accounting for individuals who never successfully transfer to adult care & $\begin{array}{l}\text { - Create a comparator group, "lost to adult follow-up" for those who } \\
\text { never have an adult visit within the study period. }{ }^{21}\end{array}$ \\
\hline Other Limitations of Administrative Data & Methodological Approaches \\
\hline $\begin{array}{l}\text { - Missing data: } \\
\text { - Physician and non-physician visits that may not be captured in admin- } \\
\text { istrative data sources } \\
\text { - Health services obtained by young adults who move away for post- } \\
\text { secondary education }\end{array}$ & $\begin{array}{l}\text { - Recognize and acknowledge these potential missing data if applicable, } \\
\text { - If available, consider collecting from alternative data sources (eg } \\
\text { medical records or survey data). }\end{array}$ \\
\hline $\begin{array}{l}\text { Risk of selection bias caused by disease severity: } \\
\text { - Under-representation of adolescents with less severe disease who } \\
\text { never see a pediatric provider but only ever see a family physician } \\
\text { or an adult specialist }\end{array}$ & $\begin{array}{l}\text { - Adjust for unmeasured confounding factors such as disease severity } \\
\text { by using a study design such as self-controlled case series (SCCS) } \\
\text { design, in which patients act as their own controls. }{ }^{25}\end{array}$ \\
\hline $\begin{array}{l}\text { Non-comprehensive outcome data: } \\
\text { - Administrative data do not holistically capture the transition experi- } \\
\text { ence (eg, patient-report experience and outcome measures and } \\
\text { social/educational/vocational outcomes) }\end{array}$ & $\begin{array}{l}\text { - Link to novel data sources such as community health surveys and } \\
\text { employment data (via tax returns), for example. }\end{array}$ \\
\hline
\end{tabular}

that the condition existed prior to receipt of adult care. Depending on the nature of the chronic condition, this may require in-patient and/or outpatient data. ${ }^{32}$ Measuring outcomes after a washout period that starts after the first adult visit ensures that events after transfer were due to the transfer and not due to clinical status during the washout period. Sensitivity analyses can be conducted to vary the length of the washout period. ${ }^{25}$ Another approach is to measure exposures and outcomes immediately before and after a specific assumed date of transfer (eg, 18th birthday) $)^{13,26-28}$ or a period of time within which transfer is assumed to occur (eg, age 17 to 18 years). ${ }^{15,29-31}$

\section{Accounting for Individuals Who Never Successfully Transfer to Adult Care}

If the definition of the transfer period requires an adult visit, create a comparator group, "lost to adult follow-up" for those who never have an adult visit within the study period. Outcomes can be measured during an empirically set post-transfer period after the last pediatric visit. ${ }^{21}$ 


\section{Risk of Selection Bias Caused by Disease Severity and Age at Diagnosis}

Adolescents with a chronic condition who never see a pediatric provider and only ever see an adult specialist may have less severe disease or differ in their access to specialized pediatric care. This situation poses a risk of selection bias by disease severity. To mitigate this risk, Zhao et al adjusted for unmeasured confounding factors such as disease severity by using a self-controlled case series (SCCS) design, in which patients act as their own controls. ${ }^{25}$ Related, if primary care in childhood is delivered by a family physician (without a pediatric specialist) there may not be a transfer to an adult provider. Further, individuals diagnosed with a chronic condition around the age of transfer who never see a pediatrician may not meet a case definition if that definition includes a visit(s) to a pediatrician.

\section{Discussion}

In this review, we highlight several methodological issues that should be considered in the design of studies that aim to identify the timing of transfer to adult care within administrative data. We highlight several limitations of existing administrative datasets and summarize methods that have been used to address each specific challenge.

There are additional limitations to identifying the time of transfer to adult care using administrative data that were not addressed by any of the papers included in the current study. For example, defining the timing of transfer based on the last pediatric and first adult care visits is challenging if non-physician visits are not captured by administrative data. Further, pediatrician and pediatric specialist physician visits may not be reliably captured by administrative datasets if physicians do not bill fee-for -service, such as those who are paid by salary or other payment mechanisms. Adolescents may also obtain health services that are not captured by administrative data if they move away for post-secondary education and use university health services, which may underestimate healthcare use after transfer. If these missing data cannot be collected from alternative data sources (eg, medical records or survey data), they should be recognized and acknowledged. Finally, although we did not identify any studies that used transfer-specific billing codes, if available, these could be used to identify the time of transfer to adult care. In addition, the exact age of transfer within and between health systems and for different conditions varies. ${ }^{32}$ A further complicating issue is that young adults may transfer some health services at one time, while other health services are transferred at a later time. For example, university students might access a new primary care provider through school before they transfer to adult oriented speciality care. Finally, administrative data do not holistically capture the transition experience (eg, patient-report experience and outcome measures and social/educational/vocational outcomes). If available and feasible, administrative data may be linked to novel data sources that contain such information such as community health surveys and employment data (via tax returns).

Based on our findings, further empiric work is needed to compare the accuracy and feasibility of differing approaches to identifying transfer. However, because none of the reported methodologies entirely overcome the challenges of identifying the time of transfer using administrative data, there is a need for integrated pediatric and adult health information systems that span this vulnerable life stage. This is important for both clinical care and for evaluation of health service interventions for transition processes and outcomes. Measuring healthcare utilization for preventive care (office visits) may not be enough to elucidate the success of transfer. Longitudinal data to measure continuity of care in early adulthood in addition to other quality indicators and qualitative data are needed to evaluate this complex process. ${ }^{34}$ Our results will inform the development of future transition care research using health administrative data.

\section{Acknowledgment}

The authors would like to thank Quenby Mahood for her assistance in developing and implementing the search strategy.

\section{Author Contributions}

All authors (Rayzel Shulman, Eyal Cohen, Eric I Benchimol, and Meranda Nakhla) made substantial contributions to conception and design, acquisition of data, or analysis and interpretation of data; drafting the article or revising it critically for important intellectual content; final approval of the version to be published; and agree to be accountable for all aspects of the work in ensuring that questions related to the accuracy or integrity of any part of the work are appropriately investigated and resolved. 


\section{Funding}

This research did not receive any specific grant from funding agencies in the public, commercial, or not for profit sectors. Meranda Nakhla was funded by Chercheurboursier clinicien Junior 2 from the Fonds de Recherche du Québec - Santé and the Ministère de la Santé et des Services Sociaux du Québec.

\section{Disclosure}

The authors have no conflicts of interest to declare.

\section{References}

1. Michaud P-A, Suris J-C, Viner R. The Adolescent with a Chronic Condition: Epidemiology, Developmental Issues and Health Care Provision. World Health Organization; 2007.

2. Peters A, Laffel L; American Diabetes Association Transitions Working G. Diabetes care for emerging adults: recommendations for transition from pediatric to adult diabetes care systems: a position statement of the American Diabetes Association, with representation by the American College of Osteopathic Family Physicians, the American Academy of Pediatrics, the American Association of Clinical Endocrinologists, the American Osteopathic Association, the Centers for Disease Control and Prevention, Children with Diabetes, The Endocrine Society, the International Society for Pediatric and Adolescent Diabetes, Juvenile Diabetes Research Foundation International, the National Diabetes Education Program, and the Pediatric Endocrine Society (formerly Lawson Wilkins Pediatric Endocrine Society). Diabetes Care. 2011;34(11):2477-2485. doi: $10.2337 / \mathrm{dc} 11-1723$

3. White PH, Cooley WC; Transitions Clinical Report Authoring G, American Academy Of $\mathrm{P}$, American Academy Of Family $\mathrm{P}$, American College Of P. Supporting the health care transition from adolescence to adulthood in the medical home. Pediatrics. 2018;142 (5):e20182587. doi:10.1542/peds.2018-2587

4. Blum RW, Garell D, Hodgman $\mathrm{CH}$, et al. Transition from child-centered to adult health-care systems for adolescents with chronic conditions. A position paper of the Society for Adolescent Medicine. J Adolesc Health. 1993;14(7):570-576. doi:10.1016/1054139X(93)90143-D

5. White PH, Cooley WC; Transitions Clinical Report Authoring Group; American Academy of Pediatrics; American Academy of Family Physicians; American College of Physicians. Supporting the Health Care Transition From Adolescence to Adulthood in the Medical Home. Pediatrics. 2018;142(5):e20182587. Pediatrics. 2019;143(2)

6. Nakhla M, Bell LE, Wafa S, Dasgupta K. Improving the transition from pediatric to adult diabetes care: the pediatric care provider's perspective in Quebec, Canada. BMJ Open Diabetes Res Care. 2017;5(1):e000390. doi:10.1136/bmjdrc-2017-000390

7. Michaud S, Dasgupta K, Bell L, et al. Adult care providers' perspectives on the transition to adult care for emerging adults with Type 1 diabetes: a cross-sectional survey. Diabet Med. 2018;35(7):846-854. doi:10.1111/dme.13627

8. Garvey KC, Telo GH, Needleman JS, Forbes P, Finkelstein JA, Laffel LM. Health care transition in young adults with type 1 diabetes: perspectives of adult endocrinologists in the U.S. Diabetes Care. 2016;39(2):190-197. doi:10.2337/dc15-1775

9. Garvey KC, Foster NC, Agarwal S, et al. Health care transition preparation and experiences in a U.S. national sample of young adults with type 1 diabetes. Diabetes Care. 2017;40(3):317-324. doi:10. 2337/dc16-1729
10. A Guideline for Transition from Paediatric to Adult Health Care for Youth with Special Health Care Needs: A National Approach. Canadian Association of Paediatric Health Centres (CAPHC); 2016.

11. Arnett JJ. Emerging adulthood. A theory of development from the late teens through the twenties. Am Psychol. 2000;55(5):469-480. doi: 10.1037/0003-066X.55.5.469

12. Garvey KC, Wolpert HA, Rhodes ET, et al. Health care transition in patients with type 1 diabetes: young adult experiences and relationship to glycemic control. Diabetes Care. 2012;35(8):1716-1722. doi: $10.2337 / \mathrm{dc} 11-2434$

13. Nakhla M, Daneman D, To T, Paradis G, Guttmann A. Transition to adult care for youths with diabetes mellitus: findings from a Universal Health Care System. Pediatrics. 2009;124(6):e1134e1141. doi:10.1542/peds.2009-0041

14. Lotstein DS, Seid M, Klingensmith G, et al. Transition from pediatric to adult care for youth diagnosed with type 1 diabetes in adolescence. Pediatrics. 2013;131(4):e1062-e1070. doi:10.1542/peds.2012-1450

15. Shulman R, Shah BR, Fu L, Chafe R, Guttmann A. Diabetes transition care and adverse events: a population-based cohort study in Ontario, Canada. Diabet Med. 2018;35(11):1515-1522. doi:10.1111/ dme.13782

16. Gabriel P, McManus M, Rogers K, White P. Outcome evidence for structured pediatric to adult health care transition interventions: a systematic review. $J$ Pediatr. 2017;188:263-269 e215. doi:10.1016/j.jpeds.2017.05.066

17. Schultz AT, Smaldone A. Components of interventions that improve transitions to adult care for adolescents with type 1 diabetes. J Adolesc Health. 2017;60(2):133-146. doi:10.1016/j.jadohealth.2016.10.002

18. Bhawra J, Toulany A, Cohen E, Moore Hepburn C, Guttmann A. Primary care interventions to improve transition of youth with chronic health conditions from paediatric to adult healthcare: a systematic review. BMJ Open. 2016;6(5):e011871. doi:10.1136/ bmjopen-2016-011871

19. Crowley R, Wolfe I, Lock K, McKee M. Improving the transition between paediatric and adult healthcare: a systematic review. Arch Dis Child. 2011;96(6):548-553. doi:10.1136/adc.2010.202473

20. Colquhoun HL, Levac D, O'Brien KK, et al. Scoping reviews: time for clarity in definition, methods, and reporting. J Clin Epidemiol. 2014;67(12):1291-1294. doi:10.1016/j.jclinepi.2014.03.013

21. Bollegala N, Benchimol EI, Griffiths AM, et al. Characterizing the posttransfer period among patients with pediatric onset IBD: the impact of academic versus community adult care on emergent health resource utilization. Inflamm Bowel Dis. 2017;23(9):1483-1491. doi:10.1097/MIB.0000000000001200

22. Hale D, Hargreaves DS. Predictors and outcomes of successful transition in diabetes: a national study of system performance using routine hospital administrative data. Arch Dis Child. 2017;102 (Supplement 1):A61-A62.

23. Mannion ML, Xie F, Baddley J, et al. Analysis of health care claims during the peri-transfer stage of transition from pediatric to adult care among juvenile idiopathic arthritis patients. Pediatr Rheumatol Online J. 2016;14(1):49. doi:10.1186/s12969-016-0107-3

24. Wisk LE, Finkelstein JA, Sawicki GS, et al. Predictors of timing of transfer from pediatric- to adult-focused primary care. JAMA Pediatr. 2015;169(6):e150951. doi:10.1001/jamapediatrics.2015.0951

25. Zhao X, Bjerre LM, Nguyen GC, et al. Health services use during transition from pediatric to adult care for inflammatory bowel disease: a population-based study using health administrative data. J Pediatr. 2018;203:280-287.e284. doi:10.1016/j.jpeds.2018.08.021

26. Blinder MA, Duh MS, Sasane M, Trahey A, Paley C, Vekeman F. Age-related emergency department reliance in patients with sickle cell disease. J Emerg Med. 2015;49(4):513-522.e511. doi:10.1016/j. jemermed.2014.12.080

27. Cohen E, Gandhi S, Toulany A, et al. Health care use during transfer to adult care among youth with chronic conditions. Pediatrics. 2016;137(3):e20152734. doi:10.1542/peds.2015-2734 
28. Dickerson AK, Klima J, Rhodes MM, O’Brien SH. Young adults with SCD in US children's hospitals: are they different from adolescents? Pediatr Blood Cancer. 2012;58(5):741-745. doi:10.1002/pbc.23262

29. Reilly NR, Green PHR, Ludvigsson JF. No difference in emergency department visits before and after transition for coeliac disease. Gut. 2017;66(11):2039-2040. doi:10.1136/gutjnl-2017-313882

30. Singh A, Yan K, Brandow AM, Panepinto JA. Longitudinal trend in emergency department reliance for pain among sickle cell disease patients in wisconsin. Blood Conf. 2017;130(Supplement 1):128.

31. Toulany A, Stukel TA, Kurdyak P, Fu L, Guttmann A. Association of primary care continuity with outcomes following transition to adult care for adolescents with severe mental illness. JAMA Network Open. 2019;2(8):e198415. doi:10.1001/jamanetworkopen.2019.8415
32. Wijlaars L, Hardelid P, Guttmann A, Gilbert R. Emergency admissions and long-term conditions during transition from paediatric to adult care: a cross-sectional study using hospital episode statistics data. BMJ Open. 2018;8(6):e021015. doi:10.1136/bmjopen-2017-021015

33. Lawrence JM, Sidell M, Li X, Desai J, O’Connor PJ, Schmittdiel JA. Timing and impact of transition from pediatric to adult care on glycemic control among adolescents and young adults with diabetes: results from the SUPREME-DM pilot study. Pediatr Diabetes. 2014;19:93-94.

34. Got transition? Tools: six core elements of health care transition and health care transition index; 2014. Accessed 2015.

\section{Publish your work in this journal}

Clinical Epidemiology is an international, peer-reviewed, open access, online journal focusing on disease and drug epidemiology, identification of risk factors and screening procedures to develop optimal preventative initiatives and programs. Specific topics include: diagnosis, prognosis, treatment, screening, prevention, risk factor modification,

Submit your manuscript here: https://www.dovepress.com/clinical-epidemiology-journal systematic reviews, risk \& safety of medical interventions, epidemiology \& biostatistical methods, and evaluation of guidelines, translational medicine, health policies \& economic evaluations. The manuscript management system is completely online and includes a very quick and fair peer-review system, which is all easy to use. 